\title{
Monohexosylceramides from Rhizopus Species Isolated from Brazilian Caatinga: Chemical Characterization and Evaluation of Their Anti-Biofilm and Antibacterial Activities
}

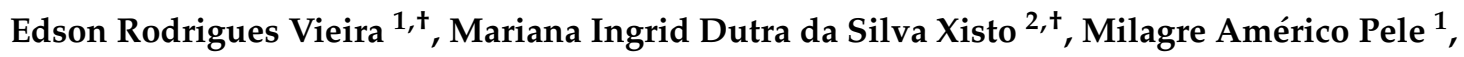 \\ Daniela Sales Alviano ${ }^{3}$, Celuta Sales Alviano ${ }^{3}$, Eliana Barreto-Bergter ${ }^{2, *}$ \\ and Galba Maria de Campos-Takaki ${ }^{1}$ \\ 1 Núcleo de Pesquisa em Ciências Ambientais e Biotecnologia, Universidade Católica de Pernambuco, \\ Recife 50050-590, PE, Brazil; edsonipubi@gmail.com (E.R.V.); phelema1@gmail.com (M.A.P.); \\ galba_takaki@yahoo.com.br (G.M.d.C.-T.) \\ 2 Laboratório de Química Biológica de Microrganismos, Instituto de Microbiologia Paulo de Góes, Centro de \\ Ciências da Saúde, Universidade Federal do Rio de Janeiro, Ilha do Fundão, \\ Rio de Janeiro 21941-902, RJ, Brazil; marylanax@gmail.com \\ 3 Laboratório de Estrutura de Microrganismos, Instituto de Microbiologia Paulo de Góes, Centro de Ciências \\ da Saúde, Universidade Federal do Rio de Janeiro, Ilha do Fundão, Rio de Janeiro 21941-902, RJ, Brazil; \\ danialviano@micro.ufrj.br (D.S.A.); alviano@micro.ufrj.br (C.S.A.) \\ * Correspondence: eliana.bergter@micro.ufrj.br; Tel.: +55-21-39386741 \\ + These authors have contributed equally to this work.
}

Received: 10 April 2018; Accepted: 26 May 2018; Published: 1 June 2018

\begin{abstract}
Monohexosylceramides (CMHs) are highly conserved fungal glycosphingolipids playing a role in several cellular processes such as growth, differentiation and morphological transition. In this study, we report the isolation, purification and chemical characterization of CMHs from Rhizopus stolonifer and R. microspores. Using positive ion mode ESI-MS, two major ion species were observed at $m / z 750$ and $m / z 766$, respectively. Both ion species consisted of a glucose/galactose residue attached to a ceramide moiety containing 9-methyl-4,8-sphingadienine with an amidic linkage to a hydroxylated C16:0 fatty acid. The antimicrobial activity of $\mathrm{CMH}$ was evaluated against Gram positive and Gram negative bacteria using the agar diffusion assay. CMH from both Rhizopus species inhibited the growth of Bacillus terrae, Micrococcus luteus (M. luteus) and Pseudomonas stutzeri (P. stutzeri) with a $\mathrm{MIC}_{50}$ of $6.25,6.25$ and $3.13 \mathrm{mg} / \mathrm{mL}$, respectively. The bactericidal effect was detected only for M. luteus and P. stutzeri, with MBC values of 25 and $6.25 \mathrm{mg} / \mathrm{mL}$, respectively. Furthermore, the action of $\mathrm{CMH}$ on the biofilm produced by methicillin-resistant Staphylococcus aureus (MRSA) was analyzed using 12.5 and $25 \mathrm{mg} / \mathrm{mL}$ of CMH from R. microsporus. Total biofilm biomass, biofilm matrix and viability of the cells that form the biofilm structure were evaluated. CMH from R. microsporus was able to inhibit the MRSA biofilm formation in all parameters tested.
\end{abstract}

Keywords: monohexosylceramides; Rhizopus; biofilm; antibacterial activities

\section{Introduction}

Fungi of the order Mucorales are commonly found in soil as saprophytes and decomposing organic matter all around the world. In Brazil these fungi are widely found in the northeastern region in arid and semi-arid ecosystems such as the Caatinga, which is an exclusively Brazilian domain in the semi-arid region of Brazil [1,2]. Some species have been described as agents of systemic infections in humans, especially in immunocompromised patients [3,4]. Rhizopus species are frequently and amply 
distributed in soils of the Caatinga in the Brazilian Northeast [2]. Little was known about the cell wall glycoconjugates of the Rhizopus species and, consequently, their specific functions in the fungal cell and in their interaction with the environment.

Ceramide monohexosides (CMHs) are highly conserved fungal glycosphingolipids with structural modifications that include different sites of unsaturation as well as fatty acid residues of varying length in their ceramide moieties [5]. CMHs play diverse roles in fungal cell processes, such as growth and morphological transition in Cryptococcus neoformans, Pseudallescheria boydii, Candida albicans, Aspergillus fumigatus and Collectotrichum gloeosporioides [6-10]. In addition, CMH are important in promoting alkaline tolerance in vitro due to the involvement of $\mathrm{CMH}$ in the regulation of membrane fungal lipid domains that lead to the redistribution of $\mathrm{CMH}$ in the membrane in an alkaline environment [11-13]. CMH also interact with defensins isolated from insects and plants [14]. Studies on $\mathrm{CMH}$ with antimicrobial activity have been performed by isolating them from plants and microorganisms, such as fungi, where they play a role in the microbial growth [15-18].

Bacterial infectious diseases are highly prevalent in tropical and developing countries such as Brazil, affecting mainly hospitalized and/or immunosuppressed individuals [19-21]. Staphylococcus aureus is one of the most frequently found bacteria and is the etiological agent of nosocomial infections that is associated with the production of biofilm on medical implants. Furthermore, it possesses a strong capacity to acquire resistance resulting in high rates of therapeutic failure [22,23]. In addition, several environmental bacteria, such as Pseudomonas stutzeri and Micrococcus luteus, have emerged as opportunistic pathogens due to the increase in the number of immunosuppressed individuals, either by immunosuppressive treatment after transplantation, HIV infection or cancer [24-27].

In this context, the goal of this work was to characterize CMHs from two species of Rhizopus, $R$. stolonifer and R. microsporus, and to evaluate the ability of these highly conserved fungal glycosphingolipids to either inhibit the growth or to kill four different bacterial species. The influence of both Rhizopus CMHs in methicillin-resistant S. aureus (MRSA) biofilm formation was also studied.

\section{Results}

\subsection{CMH Purification and Chemical Analysis}

The purification steps of $\mathrm{CMH}$ from the Rhizopus species grown in different media are shown in Figure 1A. The Folch lower layer containing neutral glycolipids was fractionated by silica gel chromatography and the fractions monitored by HPTLC on silica plates developed with chloroform: methanol: $2 \mathrm{M} \mathrm{NH}_{4} \mathrm{OH}(40: 10: 1 \mathrm{v} / \mathrm{v})$. The spots were stained by spraying with orcinol-sulfuric acid reagent (Figure 1B).

An ESI-MS analysis (positive mode) was performed to elucidate the chemical structure of purified CMHs from Rhizopus species. Lithiated molecular ions were observed at $m / z 750$ and $m / z 766$. A major lithiated ion species at $m / z 750$ was observed in R. microsporus grown in PDB and YEPD media and in R. stolonifer grown in YEPD medium, respectively. When submitted to the ESI-MS/MS analysis, these major peaks exhibited a fragment at $m / z 732$ (loss of water) and daughter ions at $m / z 588$ and $m / z 570$ (loss of water). The loss of 162 mass units common to the CMHs analyzed corresponds to the loss of a hexose residue (glucose or galactose) (Figure 2A). The prominent ion at $m / z 496$ suggests the presence of an extra hydroxyl group in the long chain base [9]. CMH from R. stolonifer grown in PDB medium presents a major lithiated species at $m / z 766$. The loss of 162 units generated daughter ions at $m / z 622$ [M-hexose $\left.+\mathrm{Li}^{+}\right]$and $m / z 604$ [M-hexose- $\mathrm{H}_{2} \mathrm{O}^{+} \mathrm{Li}^{+}$] corresponding to the ceramide monolithiated ion (Figure 2B). According to these results, we concluded that the glycosphingolipid structures consisted of a hexose, long-chain bases (4-OH-9-methyl-octadeca-4,8-sphingadienine and 4-OH-9-methyl-eicosa-4,8-sphingadienine) and hydroxylated C16:0 fatty acids. After hydrolysis with 3 M TFA, the constituent monosaccharides were identified by GC to be glucose and galactose in a ratio 1:1 from both Rhizopus species studied. 
A

\section{Fungal Cells $\mathrm{CHCL}_{3} / \mathrm{CH}_{3} \mathrm{OH}(2: 1$ and $1: 2 \mathrm{v} / \mathrm{v})$ \\ Crude extract}

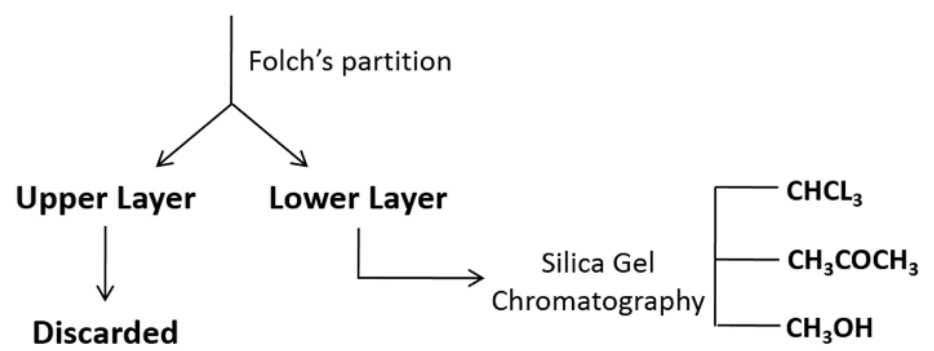

B

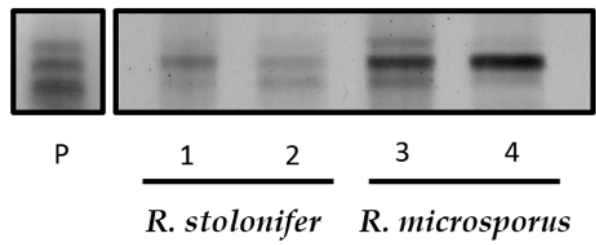

Figure 1. (A) Isolation and purification of glycosphingolipids from Rhizopus species. (B) High performance thin layer chromatography (HPTLC) of neutral glycosphingolipid fractions by silica gel column chromatography. P. CMH standard. Lane 1: Methanol fraction from $R$. stolonifer grown in potato dextrose broth (PDB). Lane 2: Methanol fraction from $R$. stolonifer grown in yeast extract-peptone-dextrose growth medium (YEPD). Lane 3: Methanol fraction from R. microsporus grown in PDB. Lane 4: Methanol fraction from R. microspores grown in YEPD. Solvent system: Chloroform/methanol/2 $\mathrm{M} \mathrm{NH}_{4} \mathrm{OH}(40: 10: 1 \mathrm{v} / v / v)$. Detection: iodine vapor and orcinol-sulfuric acid reagent.

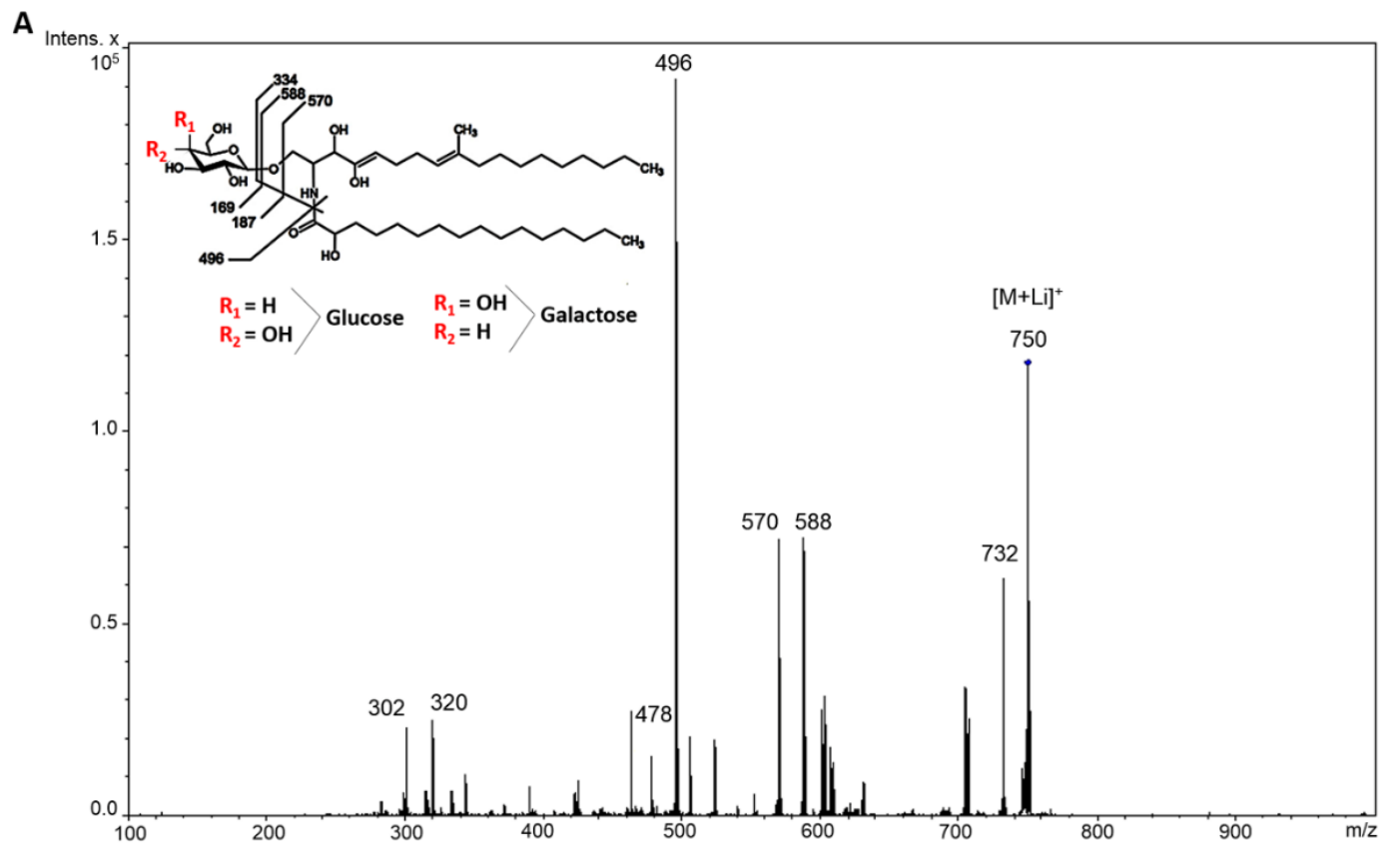

Figure 2. Cont. 
B

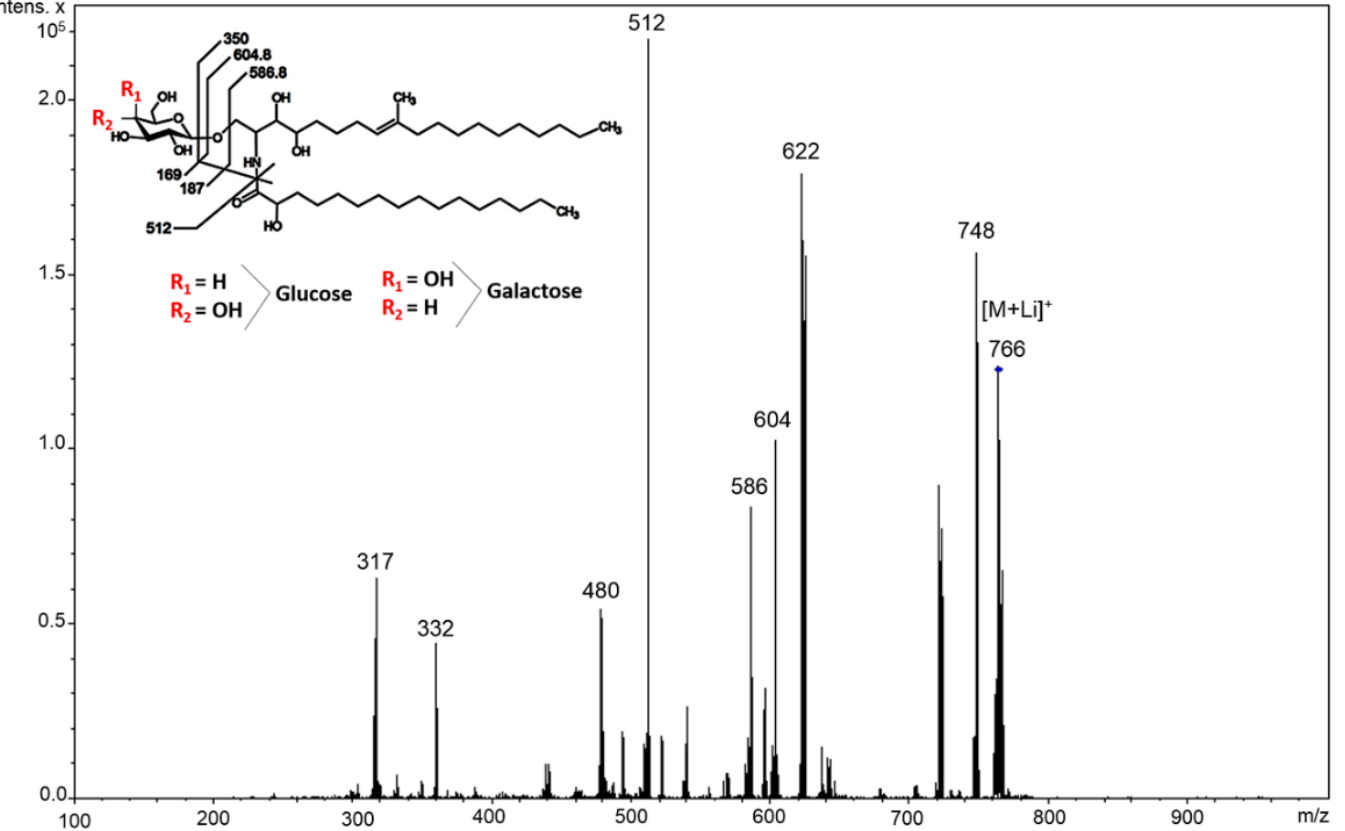

Figure 2. ESI-MS [M + Li] analysis of GlcCer/GalCer from Rhizopus species. (A) CMH from $R$. microsporus grown in PDB and YEPD, and CMH from $R$. stolonifer grown in YEPD. Major ions species at $m / z$ 750. (B) CMH from $R$. stolonifer grown in PDB. Major ions species at $m / z 766$.

\subsection{Antibacterial Activity Evaluation}

The antibacterial activity of CMHs from Rhizopus species was evaluated against six different species of indicator bacteria using the agar diffusion assay (Table 1 and Figure S1). In this assay, the lower layer from Folch partition and CMH from both species $(50 \mathrm{mg} / \mathrm{mL}-10 \mu \mathrm{L})$, were able to inhibit the growth of B. terrae, M. luteus and P. stutzeri, but there was no inhibition of other bacteria tested (B. cepacea, E. coli, S. aureus and MRSA-S. aureus). The lower layer from Folch partition containing the neutral lipids from the crude lipid extract shows lower inhibition when compared with the purified $\mathrm{CMH}$.

Table 1. Antimicrobial Activity of CMHs from Rhizopus species by Agar Diffusion Assay. Lipid samples (Folch lower layer and $\mathrm{CMH}$ ) from $R$. stolonifer and R. microsporus grown in PDB were dissolved in chloroform/methanol $(2: 1 \mathrm{v} / \mathrm{v})$ at a concentration of $50 \mathrm{mg} / \mathrm{mL}(10 \mu \mathrm{L})$. The negative control consisted of $10 \mu \mathrm{L}$ of chloroform/methanol $(2: 1 v / v)$.

\begin{tabular}{ccccc}
\hline \multirow{2}{*}{ Rhizopus Species } & \multirow{2}{*}{ Bacteria Species } & \multicolumn{3}{c}{ Inhibition (+) or No Inhibition (-) } \\
\cline { 2 - 5 } & & Control & Folch Lower Layer & CMH \\
\hline \multirow{5}{*}{ R. stolonifer } & B. cepacea & - & - & - \\
& B. terrea & - & \pm & + \\
& E. coli & - & - & - \\
& M. luteus & - & \pm & + \\
& S. aureus & - & - & - \\
& S. aureus MRSA & - & - & - \\
& P. stutzeri & - & + & + \\
\hline \multirow{6}{*}{ R. microsporus } & B. cepacea & - & - & - \\
& B. terrea & - & + & - \\
& E. coli & - & - & \pm \\
& M. luteus & - & - & - \\
& S. aureus & - & - & - \\
& S. aureus MRSA & - & + & + \\
\hline P. stutzeri & - & & - \\
\hline
\end{tabular}


To confirm the results obtained in the agar diffusion assay, the Minimum Inhibitory Concentration (MIC) and Minimum Bactericidal Concentration (MBC) values of CMH were determined against B. terrae, M. luteus and P. stutzeri (Table 2). CMHs from both species showed considerable inhibitory activity, with $\mathrm{MIC}_{50}$ of 6.25 and $3.13 \mathrm{mg} / \mathrm{mL}$ for M. luteus and P. stutzeri, respectively. CMH from $R$. stolonifer with $\mathrm{MIC}_{50}$ values of $6.25 \mathrm{mg} / \mathrm{mL}$ against $B$. terrae and $3.13 \mathrm{mg} / \mathrm{mL}$ for CMH from R. microsporus. P. stutzeri was most sensitive to $\mathrm{CMH}$, resulting in the lowest $\mathrm{MIC}_{50}$ and $\mathrm{MBC}$ values of $6.25 \mathrm{mg} / \mathrm{mL}$, followed by M. luteus with $\mathrm{MIC}_{50}$ of 6.25 and $\mathrm{MBC}$ of $25 \mathrm{mg} / \mathrm{mL}$. However, CMHs did not show antimicrobial activity against B. terrae (MBC $>50 \mathrm{mg} / \mathrm{mL}$ ) (Figure 3). Metabolic activity of the bacteria was measured using XTT-assay for all concentration tested (1.57 to $50 \mathrm{mg} / \mathrm{mL})$. CMHs from $R$. stolonifer and R. microsporus were able to reduce the viability more than $50 \%$ at the concentration of $6.25 \mathrm{mg} / \mathrm{mL}$. Streptomycin/Penicillin were used as standard references for activity against $B$. terrae, M. luteus and P. stutzeri.

Table 2. Minimum Inhibitory Concentration (MIC) and Minimum Bactericidal Concentration (MBC) values from $\mathrm{CMH}$ of $R$. stolonifer and $R$. microsporus grown in PDB media. MIC values from Streptomycin/Penicillin as a drug control.

\begin{tabular}{cccc}
\hline CMH Fraction & Bacteria & MIC $_{\mathbf{5 0}}$ & MBC \\
\hline \multirow{3}{*}{ R. stolonifer } & B. terrea & $6.25 \mathrm{mg} / \mathrm{mL}$ & $>50 \mathrm{mg} / \mathrm{mL}$ \\
& M. luteus & $6.25 \mathrm{mg} / \mathrm{mL}$ & $25 \mathrm{mg} / \mathrm{mL}$ \\
& P. stutzeri & $3.13 \mathrm{mg} / \mathrm{mL}$ & $6.25 \mathrm{mg} / \mathrm{mL}$ \\
\hline \multirow{3}{*}{ R. microsporus } & B. terrea & $3.13 \mathrm{mg} / \mathrm{mL}$ & $>50 \mathrm{mg} / \mathrm{mL}$ \\
& M. luteus & $6.25 \mathrm{mg} / \mathrm{mL}$ & $25 \mathrm{mg} / \mathrm{mL}$ \\
& P. stutzeri & $3.12 \mathrm{mg} / \mathrm{mL}$ & $6.25 \mathrm{mg} / \mathrm{mL}$ \\
\hline \multirow{3}{*}{ Streptomycin/Penicillin } & B. terrea & $0.004 \mathrm{mg} / \mathrm{mL}$ & - \\
& M. luteus & $0.004 \mathrm{mg} / \mathrm{mL}$ & - \\
& P. stutzeri & $0.004 \mathrm{mg} / \mathrm{mL}$ & - \\
\hline
\end{tabular}

$\mathrm{MIC}_{50}$ Minimal Inhibitory Concentration; MBC Minimal Bactericidal Concentration.

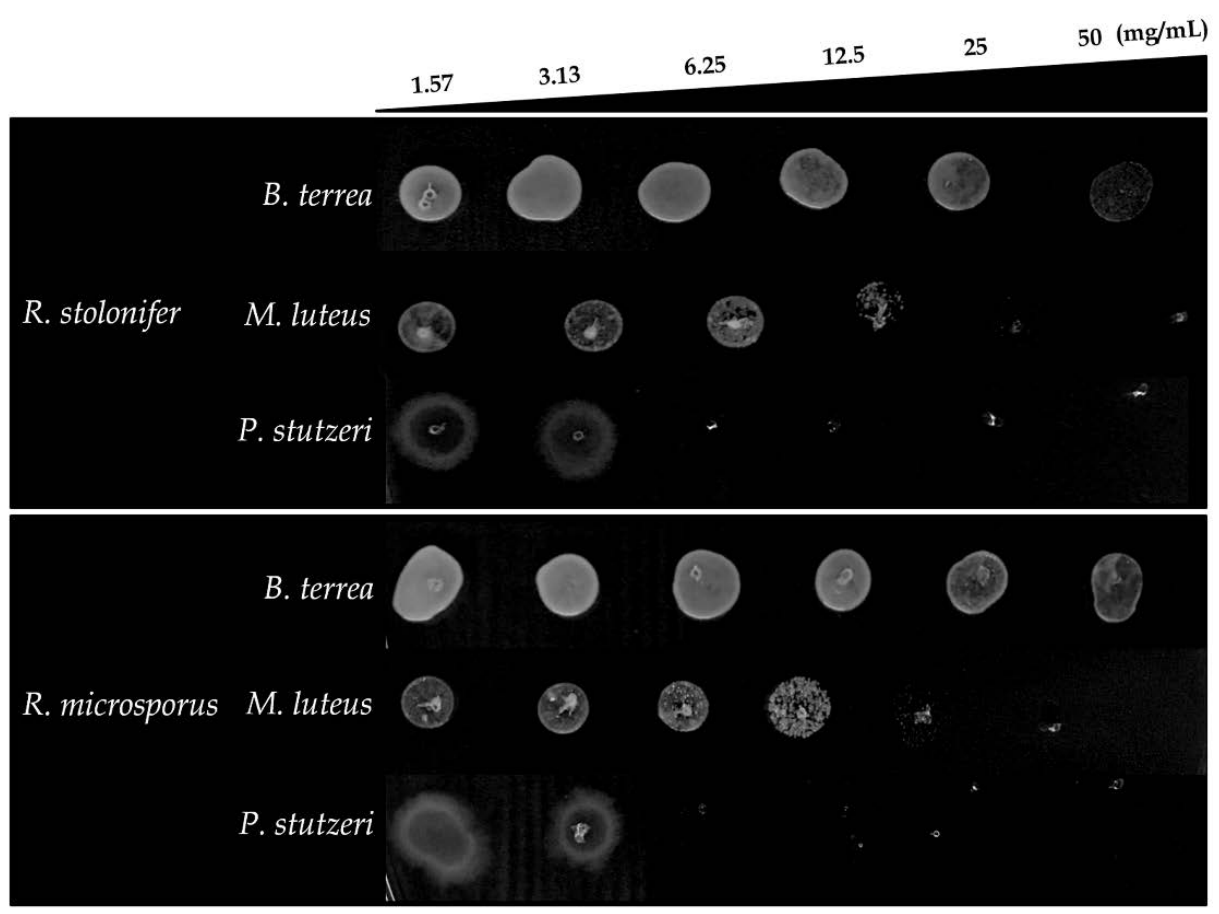

Figure 3. Minimal Bactericidal Concentration (MBC) of CMHs from Rhizopus species against B. terrea, M. luteus and P. stutzeri analyzed by dot spot technique. 


\subsection{Evaluation of Anti-Biofilm Activity}

The effect of $\mathrm{CMH}(\mathrm{m} / \mathrm{z} 750)$ from $R$. microsporus on the biofilm produced by methicillin resistant S. aureus (MRSA) was analyzed using two different concentrations ( 12.5 and $25 \mathrm{mg} / \mathrm{mL})$. CMH was not able to inhibit the growth of MRSA, however it could interfere with biofilm formation. Therefore, S. aureus (MRSA) was chosen as indicator bacterium due to its multi-drug resistance and ability to form biofilm. Representative biofilms formed by MRSA-S. aureus are shown in Figure 4A and the absorbance was determined at $600 \mathrm{~nm}$ (Figure 4B). Absorbance values, mean, standard deviation and standard error are represented in Figure 4C. Biofilm production on polystyrene microplates was also analyzed by correlating the results of three different analyses: The total biofilm biomass (including biofilm structure depleted of planktonic cells) was evaluated using crystal violet assay (Figure 5A, Table S1). The production of extracellular matrix was, evaluated by safranin assay (Figure 5B, Table S1), and the metabolic activity of the biofilm was quantified using XTT-assay (Figure 5C, Table S1). CMH from $R$. microsporus was able to reduce the total biofilm biomass in both concentrations tested. The biofilm matrix was also reduced and the metabolic activity of the biofilm was drastically decreased. Although $\mathrm{CMH}$ was not able to kill MRSA, it was could capably interfere on the biofilm structure formation.

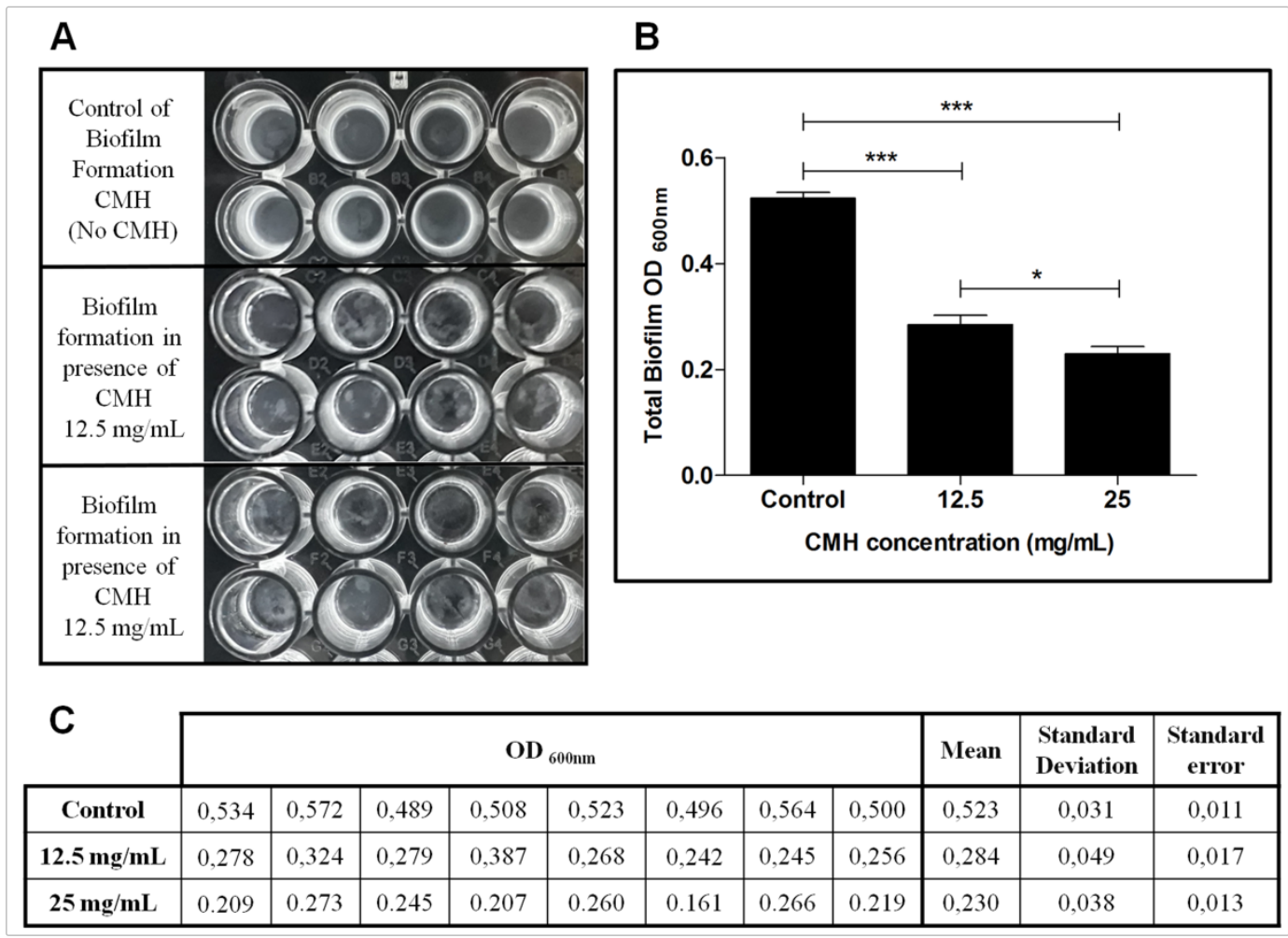

Figure 4. Effect of CMH on MRSA-S. aureus biofilm formation. (A) Representative biofilm formation at different concentration of CMH (12.5 and $25 \mathrm{mg} / \mathrm{mL}$ ) and control. (B) Quantification of total biofilm formed in presence or absence of CMH. Absorbance determined at $600 \mathrm{~nm}$. (C) CMH effect on MRSA biofilm formation determined by absorbance measurement at $600 \mathrm{~nm}$. Mean, standard deviation and standard error are represented. Statistical differences $\left({ }^{*} p<0.05,{ }^{* *} p<0.001,{ }^{* * *} p<0.0001\right)$ are represented by asterisks (ns = not significant). 
A

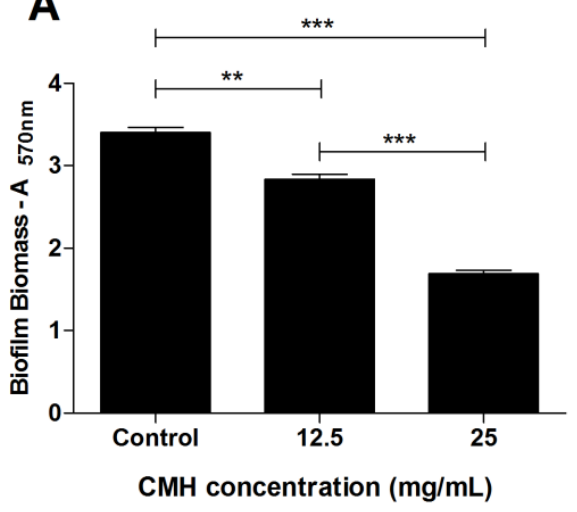

C

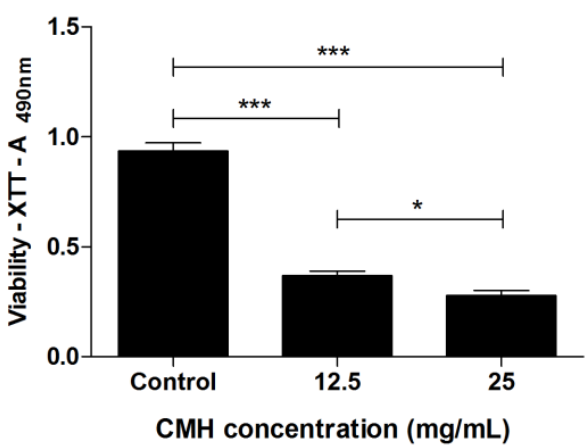

B

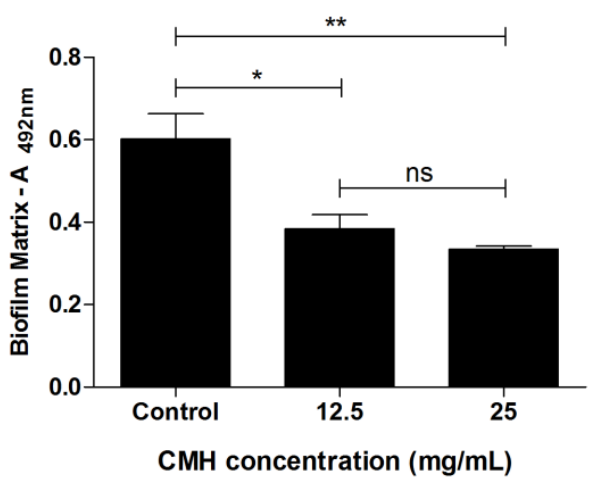

Figure 5. Effect of CMH on MRSA-S. aureus biofilm formation, after $24 \mathrm{~h}$ of growth. (A) Total biomass of the biofilm was quantified by crystal violet assay. (B) The biofilm matrix was quantified by safranin assay. (C) Metabolic activity of the cells inside the biofilm was detected by XTT-reduction assay. Statistical differences $\left({ }^{*} p<0.05,{ }^{* *} p<0.001,{ }^{* * *} p<0.0001\right.$ ) are represented by asterisks (ns = not significant $)((\mathbf{A})=$ absorbance). Control represent MRSA growth in absence of $\mathrm{CMH}$. Values represent the mean \pm S.D. of three independent experiments performed in triplicate.

\section{Discussion}

Glycosphingolipids are membrane lipids distributed among all eukaryotic cells. They are highly enriched in the plasma membrane and are present in membrane microdomains together with sterols and proteins. Glycosylceramides are the main neutral glycosphingolipids expressed in fungal pathogens [7,28,29], and may have glucose and galactose as glycan motifs [30]. Glycosphingolipids play an important role in relevant cellular functions such as cell growth, cell adhesion and motility, carbohydrate-carbohydrate interactions and also act as potential antifungal agents [31,32]. In this work, CMHs obtained from $R$. stolonifer and R. microsporus grown in PDB or YEPD medium had their chemical structures elucidated by electrospray ionization mass spectrometry (ESI-MS) and by gas chromatography (GC). In this work, the role of $\mathrm{CMH}$ in inhibiting the growth of several bacterial species or the biofilm formation in methicillin-resistant $S$. aureus (MRSA) was also studied.

The major glycosphingolipids detected in Rhizopus species grown in PDB and YEPD are $N$-2'-hydroxyhexadecanoyl-1-O- $\beta$-D-glucopyranosyl-4-OH-9-methyl-octadeca-4,8-sphingadienine and $N$-2'-hydroxyhexadecanoyl-1-O- $\beta$-D-galactopyranosyl-4-OH-9-methyl-octadeca-4,8-sphingadienine with a ratio of 1:1. The main difference between $R$. stolonifer CMHs grown in PDB medium and the other Rhizopus species described above is the presence of 4-OH-9-methyl-eicosa-4,8-sphingadienine as the main long chain base. To our knowledge, this is the first time that different CMHs structures were identified in R. stolonifer grown in different culture media. CMHs with ceramide mono-, di-, tri-, tetraand pentasaccharides have been found in other Zygomycetes species as Mucor hiemalis [33]. 
Currently, many clinically important and emerging pathogens are resistant to all or almost all antibiotics tested. This is a serious public health problem with great medical and social dimensions. The indiscriminate use of antibiotics has greatly increased the number of different bacterial species resistant to antimicrobials, which are normally used in clinical settings [34]. Therefore, there is an urgency for studies looking for the discovery of new antimicrobial agents.

In this context, CMHs isolated from $R$. stolonifer and R. microsporus grown in PDB were tested against both pathogenic and opportunistic bacteria, such as B. cepacea, B. terrae and E. coli (Gram negative bacteria), and M. luteus, P. stutzeri and S. aureus (Gram positive bacteria). In the agar diffusion assay, $50 \mathrm{mg} / \mathrm{mL}$ of the Folch lower phase (containing neutral lipids) or purified CMH from Rhizopus species showed antimicrobial activity against B. terrae, M. luteus and P. stutzeri. The growth of B. cepacea, E. coli, S. aureus and MRSA was not affected by either the Folch lower phase or by CMH. The best antimicrobial potential was observed for $\mathrm{CMH}$ from both fungi, with $\mathrm{MIC}_{50}$ values of $3.13 \mathrm{mg} / \mathrm{mL}$ against $P$. stutzeri, followed by M. luteus with MIC $_{50} 6.25 \mathrm{mg} / \mathrm{mL}$. The MIC values for CMH from $R$. stolonifer against $B$. terrae was $6.25 \mathrm{mg} / \mathrm{mL}$ and from $R$. microsporus was $3.13 \mathrm{mg} / \mathrm{mL}$. The CMHs from both fungi were able to decrease the viability of the three indicator bacteria tested. However, the bactericidal activity of $\mathrm{CMH}$ was only detected against M. luteus and P. stutzeri, with MBC values of 25 and $6.25 \mathrm{mg} / \mathrm{mL}$, respectively. Previous work has shown that glycosphingolipids, which are amphipathic molecules, may present several biological activities, such as antimicrobial and biosurfactant actions [35].

An important survival strategy of microorganisms is the formation of biofilm, which is considered an adaptation to hostile environmental conditions [36]. Biofilms can be defined as a community of cells attached to a substrate embedded in a matrix of extracellular polymeric substances. Inside the structure of the biofilm, channels are formed that allow the passage of water, oxygen and nutrients [37]. The biofilm produced by $S$. aureus is an important virulence factor associated with many localized infections. In this work, although CMH did not inhibit the growth of MRSA, we investigated whether it would be able to inhibit the formation or disaggregation of the biofilm structure formed by MRSA. The biofilm produced by MRSA in the presence or absence of CMH was evaluated by three parameters: Total biofilm biomass, biofilm matrix and viability of the biofilm-forming cells. The results showed that both $\mathrm{CMH}$ concentrations ( 12.5 and $25 \mathrm{mg} / \mathrm{mL}$ ) were able to influence all tested parameters. Biosurfactants isolated from Lactobacillus jensenii and L. rhamnosus showed anti-biofilm activities against clinical Multidrug Resistant (MDR) strains of Acinetobacter baumannii, E. coli, and S. aureus (MRSA) at the concentrations of 25 and $50 \mathrm{mg} / \mathrm{mL}$ [38]. However, the chemical structure of these molecules has not been elucidated.

CMH could inhibit MRSA adhesion which represents the initial stage of biofilm formation [35]. However, studies are needed to investigate possible synergism between CMHs from Rhizopus species and the antibiotics used routinely for the treatment of MRSA infections.

\section{Material and Methods}

\subsection{Microorganisms and Culture Conditions}

Rhizopus stolonifer UPC1300 and Rhizopus microsporus var. microsporus UPC1304, isolated from the Brazilian Caatinga area, were supplied by the Culture Collection (RENNORFUN) from the Catholic University of Pernambuco, Recife, Brazil. Strains were maintained in Sabouraud agar solid medium under refrigeration at $4{ }^{\circ} \mathrm{C}$. Cells were inoculated in Erlenmeyer flasks containing $200 \mathrm{~mL}$ of potato dextrose broth (PDB) and / or YEPD (glucose $2 \%$, peptone $2 \%$, yeast extract $1 \%$ ), and incubated at room temperature for 7 days with orbital shaking (pre-inoculum). Cultures $(200 \mathrm{~mL})$ were then transferred to the same medium $(3 \mathrm{~L}$ ) and incubated for a further 7 days at the same temperature with shaking. At the end, the mycelium was filtered, washed with distilled water, and stored at $-20^{\circ} \mathrm{C}$. 


\subsection{Extraction and Purification of CMH from R. stolonifer and R. microsporus}

Total lipids from intact hyphae of $R$. stolonifer and $R$. microsporus grown in PDB or YEPD were successively extracted at room temperature using chloroform/methanol at ratios 2:1 and 1:2 (v/v), as described [7]. The crude lipid extracts were partitioned with chloroform/methanol/ $0.45 \% \mathrm{KCl}$ (8:4:3 $v / v)$ as described by Folch et al. (1957) [39]. The Folch lower layer containing neutral lipids, glycosphingolipids and phospholipids was fractionated on a silica gel column which was sequentially eluted with chloroform, acetone and then methanol [12]. The recovery of glycosphingolipids by elution with methanol was monitored by thin-layer chromatography (TLC), on silica gel plates developed with chloroform/methanol/2 M ammonium hydroxide, 40:10:1 (v/v). The spots were visualized with iodine and by charring with orcinol $/ \mathrm{H}_{2} \mathrm{SO}_{4}$.

\subsection{Sugar Analysis}

Glycosphingolipids were hydrolyzed with $3 \mathrm{M}$ trifluoroacetic acid at $100{ }^{\circ} \mathrm{C}$ for $3 \mathrm{~h}$ and the released monosaccharides were characterized by HPTLC developed with n-butanol/acetone/water $(4: 5: 1 v / v)$ and visualized by spraying with orcinol-sulfuric acid reagent. The monosaccharides were converted to their alditol acetate derivatives and quantified by GC using the chromatograph GC-2010 Plus-Shimadzu, with a SH-RTX-5 capillary column (30 m, $0.25 \mathrm{~mm}$ ID, $0.25 \mathrm{Um}$ df), programmed for an initial isothermal period of $10 \mathrm{~min}$ at $190{ }^{\circ} \mathrm{C}$, and subsequent temperature increase of $2{ }^{\circ} \mathrm{C} / \mathrm{min}$, until $210{ }^{\circ} \mathrm{C}$ were reached $[40,41]$.

\subsection{ESI-MS Analysis}

CMHs were analyzed by electrospray ionization (ESI-MS) in positive (ESI+) ion mode, using an ESI-ion Trap instrument (Model Amazon SL, Bruker, Germany). CMHs were diluted in chloroform/methanol/water $(5: 4: 1 \mathrm{v} / \mathrm{v})$, containing $1 \mathrm{mM}$ lithium chloride and analyzed via direct injection using a microsyringe pump (Hamilton) [42]. Nitrogen was used as nebulizer and carrier gas.

\subsection{Antimicrobial Assay}

\subsubsection{Bacterial Strains}

Burkholderia cepacea (American Type Culture Collection, ATCC 25416), B. terrea BS001 (Microbial Ecology culture collection, University of Groningen, Groningen, The Netherlands), Escherichia coli (American Type Culture Collection, ATCC11229), Micrococcus luteus (American Type Culture Collection, ATCC4698) Methicillin Resistant Staphylococcus aureus-MRSA (American Type Culture Collection, ATCC9393), Pseudomonas stutzeri R55 (Laboratory of Molecular Microbial Ecology and Microbial Diversity Culture Collection, Instituto de Microbiologia Paulo de Góes, Universidade Federal do Rio de Janeiro/UFRJ). Bacteria were grown at $37^{\circ} \mathrm{C}$ in Luria-Bertani (LB) broth (peptone $10 \mathrm{~g} / \mathrm{L}$, yeast extract $5 \mathrm{~g} / \mathrm{L}$ and $\mathrm{NaCl} 5 \mathrm{~g} / \mathrm{L})$.

\subsubsection{Antimicrobial Activity Assay}

Antimicrobial activity of $\mathrm{CMH}[50 \mathrm{mg} / \mathrm{mL}$ in chloroform/methanol $(2: 1 v / v)]$ was determined against all bacterial strains by the agar diffusion method with modifications. Briefly, $10 \mu \mathrm{L}$ of $\mathrm{CMH}$ $(50 \mathrm{mg} / \mathrm{mL})$ were spotted on a Petri dish containing LB agar medium. After evaporation of the organic solvents, an inoculum of each bacterial strain containing approximately $1.5 \times 10^{8}$ colony forming units $(\mathrm{CFU} / \mathrm{mL})$ prepared in Luria-Bertani broth medium was spread out on the plates, and the plates were incubated for $24 \mathrm{~h}$ at $37^{\circ} \mathrm{C}$. A positive control with inoculum without $\mathrm{CMH}$ was included. Growth inhibition zones were evidenced using MTT (Thiazolyl Blue Tetrazolium Bromide-Sigma Aldrich, St. Louis, MO, USA) [43]. 


\subsubsection{Determination of MIC and MBC}

MIC was evaluated by the dilution method in $\mathrm{LB}$ broth. $\mathrm{CMH}$ concentrations ranging from $15.7 \mathrm{mg} / \mathrm{mL}$ to $50 \mathrm{mg} / \mathrm{mL}$ were tested and $10 \mu \mathrm{L}$ of the bacterial suspension containing $1.5 \times 10^{8} \mathrm{CFU} / \mathrm{mL}\left(0.1 \mathrm{OD}_{600 \mathrm{~nm}}\right)$ were added to each well and incubated at $37^{\circ} \mathrm{C}$ for $24 \mathrm{~h}$. DMSO was used as control ( $5 \%$ in LB broth medium) and streptomycin/penicilin was used as a reference compound $(8-0.015 \mu \mathrm{g} / \mathrm{mL})$. After $24 \mathrm{~h}$, the plates were read at $600 \mathrm{~nm}$ to evaluate the $\mathrm{MIC}_{50}$. After MICs reading, MBC (minimal bactericidal concentration) was determined by subculturing an aliquot of $10 \mu \mathrm{L}$ from each well that showed complete growth inhibition in LB agar medium without addition of $\mathrm{CMH}$ and the bacterial growth was evaluated for the MBC determination. After $24 \mathrm{~h}$, the MBC values were defined as the lowest concentration of $\mathrm{CMH}$ able of eliminate bacteria [44]. The experiments were carried out in duplicates. Following the MIC assays, cell viability was evaluated using XTT reduction assay (XTT sodium salt-0.5 mg/mL—Sigma Aldrich, St. Louis, MO, USA) [45].

\subsubsection{Effect of CMH on Inhibition of MRSA ATCC9393 Biofilm}

$50 \mu \mathrm{L}$ of MRSA ATCC9393 suspension $\left(0.1\right.$ OD $\left._{600 \mathrm{~nm}}\right)$ in Tryptic Soy Broth (TSB) supplemented with $1 \%$ glucose were mixed with $50 \mu \mathrm{L}$ of $\mathrm{CMH}(12.5$ and $25 \mathrm{mg} / \mathrm{mL})$ from $R$. microspores and added to each well of a 96-well polystyrene plate. Culture medium with the bacterial suspension was used as negative control. After $24 \mathrm{~h}$ incubation at $37^{\circ} \mathrm{C}$, the formed biofilm was gently washed with sterile distilled water to remove planktonic cells, air-dried for $10 \mathrm{~min}$ and stained with $0.5 \%$ crystal violet for $10 \mathrm{~min}$ (total biofilm biomass) or $1 \%$ safranin for $10 \mathrm{~min}$ (biofilm matrix). The staining solutions were discarded and the biofilms were rinsed gently twice with sterile distilled water. The crystal violet impregnated in the biofilm was dissolved in $200 \mu \mathrm{L}$ of ethanol $(95 \%, v / v)$, and the colored solution was read at an absorbance of $595 \mathrm{~nm}$ using a spectrophotometer (Spectra MAX 340 Tunable; Molecular Devices Ltd., San Jose, CA, USA). Safranin was dissolved in water (100 $\mu \mathrm{L})$, and the absorbance read at $492 \mathrm{~nm}$. Viability analysis of the cells in the biofilm was performed by XTT reduction assay. Biofilms were washed with sterile distilled water, and $150 \mu \mathrm{L}$ of XTT solution were added to each well. The XTT solution was prepared by dissolving $5 \mathrm{mg}$ of XTT in $10 \mathrm{~mL}$ of water, followed by the addition of 400 $\mu \mathrm{L}$ Menadione solution $\left(0.17 \mathrm{mg} / \mathrm{mL}\right.$ in acetone). After incubation at $37^{\circ} \mathrm{C}$ for $1 \mathrm{~h}$ under protection from light, the absorbance of the colored solution was measured at $490 \mathrm{~nm}$.

\subsection{Statistical Analysis}

All statistical analyses were performed using GraphPad Prism 5.0 software (GraphPad, San Diego, CA, USA). A variance two-way ANOVA was performed using Tukey's and Bonferroni's comparisons tests to evaluate the biofilm formation.

Supplementary Materials: The following are available, Figure S1: Antimicrobial Activity of CMHs from $R$. stolonifer and R. microsporus against a panel of Gram-positive and Gram-negative bacterium by agar disc diffusion method. CMH or Folch lower layer (Folch $\downarrow$ ) were dissolved in chloroform/methanol $(2: 1 \mathrm{v} / v)$ at a concentration of $50 \mathrm{mg} / \mathrm{mL}$. Each spot contained $10 \mu \mathrm{L}$. The control spot contained $10 \mu \mathrm{L}$ of chloroform $/ \mathrm{methanol}$ $(2: 1 v / v)$. Growth inhibition zones were evidenced by MTT assay. Table S1: Effect of CMH on MRSA-S. aureus biofilm formation. Analyses were done correlating the results of total biofilm biomass (evaluated by crystal violet assay, $A_{570 \mathrm{~nm}}$ ), production of extracellular matrix (evaluated by safranin assay, $\mathrm{A}_{492 \mathrm{~nm}}$ ) and metabolic activity (quantified by XTT-assay, $\mathrm{A}_{490 \mathrm{~nm}}$ ). Mean, standard deviation (SD) and standard error (SE) are also shown. (A = absorbance).

Author Contributions: Conceived and designed the experiments: E.R.V.; M.I.D.d.S.X.; E.B.-B. Performed the experiments: E.R.V.; M.I.D.d.S.X.; M.A.P.; D.S.A. Analyzed the data: M.I.D.d.S.X.; E.R.V.; M.A.P.; E.B.-B. Contributed reagents/materials/analysis tools: E.B.-B.; C.S.A.; D.S.A.; G.M.d.C.-T. Wrote the paper: M.I.D.d.S.X.; E.B.-B.; D.S.A.; G.M.d.C.-T.

Funding: This research was funded by Conselho Nacional de Desenvolvimento Científico e Tecnológico (CNPq) grant number \#150072/2017-1/PDJ, Fundação de Amparo à Pesquisa do Estado do Rio de Janeiro (FAPERJ) and Coordenação de Aperfeiçoamento de Pessoal de Nível Superior (CAPES). 
Acknowledgments: This work was supported by grants from the Conselho Nacional de Desenvolvimento Científico e Tecnológico (CNPq \# 150072/2017-1/PDJ), Fundação de Amparo à Pesquisa do Estado do Rio de Janeiro (FAPERJ), Coordenação de Aperfeiçoamento de Pessoal de Nível Superior (CAPES). We thank the Centro de Espectrometria de Massas de Biomoleculas (CEMBIO) from Universidade Federal do Rio de Janeiro for ESI-MS analysis. We thank Walter Oelemann for advice, encouragement and critical reading of the manuscript. The funders had no role in study design, data collection and analysis, decision to publish, or preparation of the manuscript.

Conflicts of Interest: The authors declare no conflict of interest.

\section{References}

1. De Azevedo Santiago, A.L.C.M.; dos Santos, P.J.P.; Maia, L.C. Mucorales from the semiarid of Pernambuco, Brazil. Braz. J. Microbiol. 2013, 44, 299-305. [CrossRef] [PubMed]

2. Lima, D.X.; De Azevedo Santiago, A.L.C.M.; De Souza-Motta, C.M. Diversity of mucorales in natural and degraded semi-arid soils. Braz. J. Bot. 2016, 39, 1127-1133. [CrossRef]

3. Lackner, M.; Caramalho, R.; Lass-Flörl, C. Laboratory diagnosis of mucormycosis: Current status and future perspectives. Future Microbiol. 2014, 9, 683-695. [CrossRef] [PubMed]

4. Ribes, J.A.; Vanover-Sams, C.L.; Baker, D.J. Zygomycetes in human disease. Clin. Microbiol. Rev. 2000, 13, 236-301. [CrossRef] [PubMed]

5. Pinto, M.R.; Rodrigues, M.L.; Travassos, L.R.; Haido, R.M.T.; Wait, R.; Barreto-Bergter, E. Characterization of glucosylceramides in Pseudallescheria boydii and their involvement in fungal differentiation. Glycobiology 2002, 12, 251-260. [CrossRef] [PubMed]

6. Barreto-Bergter, E.; Pinto, M.R.; Rodrigues, M.L. Structure and biological functions of fungal cerebrosides. An. Acad. Bras. Ciênc. 2004, 76, 67-84. [CrossRef] [PubMed]

7. Barreto-Bergter, E.; Sassaki, G.L.; de Souza, L.M. Structural analysis of fungal cerebrosides. Front. Microbiol. 2011, 2, 239. [CrossRef] [PubMed]

8. Da Silva, A.F.C.; Rodrigues, M.L.; Farias, S.E.; Almeida, I.C.; Pinto, M.R.; Barreto-Bergter, E. Glucosylceramides in colletotrichum gloeosporioides are involved in the differentiation of conidia into mycelial cells. FEBS Lett. 2004, 561, 137-143. [CrossRef]

9. Nimrichter, L.; Cerqueira, M.D.; Leitão, E.A.; Miranda, K.; Nakayasu, E.S.; Almeida, S.R.; Almeida, I.C.; Alviano, C.S.; Barreto-Bergter, E.; Rodrigues, M.L. Structure, cellular distribution, antigenicity, and biological functions of Fonsecaea pedrosoi ceramide monohexosides. Infect. Immun. 2005, 73, 7860-7868. [CrossRef] [PubMed]

10. Rodrigues, M.L.; Travassos, L.R.; Miranda, K.R.; Franzen, A.J.; Rozental, S.; de Souza, W.; Alviano, C.S.; Barreto-Bergter, E. Human antibodies against a purified glucosylceramide from Cryptococcus neoformans inhibit cell budding and fungal growth. Infect. Immun. 2000, 68, 7049-7060. [CrossRef] [PubMed]

11. Ramamoorthy, V.; Cahoon, E.B.; Thokala, M.; Kaur, J.; Li, J.; Shah, D.M. Sphingolipid c-9 methyltransferases are important for growth and virulence but not for sensitivity to antifungal plant defensins in Fusarium graminearum. Eukaryot. Cell 2009, 8, 217-229. [CrossRef] [PubMed]

12. Rollin-Pinheiro, R.; Singh, A.; Barreto-Bergter, E.; Del Poeta, M. Sphingolipids as targets for treatment of fungal infections. Future Med. Chem. 2016, 8, 1469-1484. [CrossRef] [PubMed]

13. Saito, K.; Takakuwa, N.; Ohnishi, M.; Oda, Y. Presence of glucosylceramide in yeast and its relation to alkali tolerance of yeast. Appl. Microbiol. Biotechnol. 2006, 71, 515-521. [CrossRef] [PubMed]

14. Thevissen, K.; Warnecke, D.C.; François, I.E.J.A.; Leipelt, M.; Heinz, E.; Ott, C.; Zähringer, U.; Thomma, B.P.H.J.; Ferket, K.K.A.; Cammue, B.P.A. Defensins from insects and plants interact with fungal glucosylceramides. J. Biol. Chem. 2004, 279, 3900-3905. [CrossRef] [PubMed]

15. Cateni, F.; Zilic, J.; Falsone, G.; Scialino, G.; Banfi, E. New cerebrosides from Euphorbia peplis L.: Antimicrobial activity evaluation. Bioorgan. Med. Chem. Lett. 2003, 13, 4345-4350. [CrossRef]

16. Derengowski, L.S.; De-Souza-Silva, C.; Braz, S.V.; Mello-De-Sousa, T.M.; Báo, S.N.; Kyaw, C.M.; Silva-Pereira, I. Antimicrobial effect of farnesol, a Candida albicans quorum sensing molecule, on Paracoccidioides brasiliensis growth and morphogenesis. Ann. Clin. Microbiol. Antimicrob. 2009, 8, 13. [CrossRef] [PubMed] 
17. Shu, R.G.; Wang, F.W.; Yang, Y.M.; Liu, Y.X.; Tan, R.X. Antibacterial and xanthine oxidase inhibitory cerebrosides from Fusarium sp. IFB-121, and endophytic fungus in quercus variabilis. Lipids 2004, 39, 667-673. [CrossRef] [PubMed]

18. Wu, Z.-P.; Chen, Y.; Xia, B.; Wang, M.; Dong, Y.-F.; Feng, X. Two novel ceramides with a phytosphingolipid and a tertiary amide structure from Zephyranthes candida. Lipids 2009, 44, 63-70. [CrossRef] [PubMed]

19. Ribeiro, P.C.S.; Monteiro, A.S.; Marques, S.G.; Monteiro, S.G.; Monteiro-Neto, V.; Coqueiro, M.M.M.; Marques, A.C.G.; de Jesus Gomes Turri, R.; Santos, S.G.; Bomfim, M.R.Q. Phenotypic and molecular detection of the bla(KPC) gene in clinical isolates from inpatients at hospitals in São Luis, MA, Brazil. BMC Infect. Dis. 2016, 16, 737. [CrossRef] [PubMed]

20. Rossi Gonçalves, I.; Ferreira, M.L.; Araujo, B.F.; Campos, P.A.; Royer, S.; Batistão, D.W.F.; Souza, L.P.; Brito, C.S.; Urzedo, J.E.; Gontijo-Filho, P.P.; et al. Outbreaks of colistin-resistant and colistin-susceptible KPC-producing klebsiella pneumoniae in a brazilian intensive care unit. J. Hosp. Infect. 2016, 94, 322-329. [CrossRef] [PubMed]

21. Tognim, M.C.B.; Cardoso, C.L. Nosocomial outbreaks in brazil: Can they be controlled? J. Hosp. Infect. 2016, 94, 320-321. [CrossRef] [PubMed]

22. Lima-e-Silva, A.A.; Silva-Filho, R.G.; Fernandes, H.M.Z.; Saramago, C.S.M.; Viana, A.S.; Souza, M.J.; Nogueira, E.M. Sub-inhibitory concentrations of rifampicin strongly stimulated biofilm production in S. aureus. Open Microbiol. J. 2017, 11, 142-151. [CrossRef] [PubMed]

23. Rodríguez-Rojas, A.; Makarova, O.; Rolff, J. Antimicrobials, stress and mutagenesis. PLoS Pathog. 2014, 10, e1004445. [CrossRef] [PubMed]

24. Ioannou, A.; Xenophontos, E.; Karatsi, A.; Petrides, C.; Kleridou, M.; Zintilis, C. Insidious manifestation of pyogenic liver abscess caused by streptococcus intermedius and micrococcus luteus: A case report. Oxf. Med. Case Rep. 2016, 2016, 1-3. [CrossRef] [PubMed]

25. Lalucat, J.; Bennasar, A.; Bosch, R.; García-Valdés, E.; Palleroni, N.J. Biology of Pseudomonas stutzeri. Microbiol. Mol. Biol. Rev. 2006, 70, 510-547. [CrossRef] [PubMed]

26. Miltiadous, G.; Elisaf, M. Native valve endocarditis due to micrococcus luteus: A case report and review of the literature. J. Med. Case Rep. 2011, 5, 251. [CrossRef] [PubMed]

27. Miron, D.; Keness, Y.; Bor, N.; Spiegel, R.; Horowitz, Y. Pseudomonas stutzeri knee arthritis in a child: Case report and review. J. Pediatr. Orthop. B 2007, 16, 419-421. [CrossRef] [PubMed]

28. Guimarães, L.L.; Toledo, M.S.; Ferreira, F.A.S.; Straus, A.H.; Takahashi, H.K. Structural diversity and biological significance of glycosphingolipids in pathogenic and opportunistic fungi. Front. Cell. Infect. Microbiol. 2014, 4, 138. [CrossRef] [PubMed]

29. Longo, L.V.G.; Nakayasu, E.S.; Gazos-Lopes, F.; Vallejo, M.C.; Matsuo, A.L.; Almeida, I.C.; Puccia, R. Characterization of cell wall lipids from the pathogenic phase of Paracoccidioides brasiliensis cultivated in the presence or absence of human plasma. PLoS ONE 2013, 8, e63372. [CrossRef] [PubMed]

30. Takahashi, H.K.; Toledo, M.S.; Suzuki, E.; Tagliari, L.; Straus, A.H. Current relevance of fungal and trypanosomatid glycolipids and sphingolipids: Studies defining structures conspicuously absent in mammals. An. Acad. Bras. Ciênc. 2009, 81, 477-488. [CrossRef] [PubMed]

31. Hakomori, S. Glycosynapses: Microdomains controlling carbohydrate-dependent cell adhesion and signaling. An. Acad. Bras. Ciênc. 2004, 76, 553-572. [CrossRef] [PubMed]

32. Hakomori, S.-I. Structure and function of glycosphingolipids and sphingolipids: Recollections and future trends. Biochim. Biophys. Acta 2008, 1780, 325-346. [CrossRef] [PubMed]

33. Aoki, K.; Uchiyama, R.; Yamauchi, S.; Katayama, T.; Itonori, S.; Sugita, M.; Hada, N.; Yamada-Hada, J.; Takeda, T.; Kumagai, H.; et al. Newly discovered neutral glycosphingolipids in aureobasidin a-resistant zygomycetes: Identification of a novel family of gala-series glycolipids with core gal $\alpha 1-6 g a l \beta 1-6 g a l \beta$ sequences. J. Biol. Chem. 2004, 279, 32028-32034. [CrossRef] [PubMed]

34. Weinstein, R.A. Controlling antimicrobial resistance in hospitals: Infection control and use of antibiotics. Emerg. Infect. Dis. 2001, 7, 188-192. [CrossRef] [PubMed]

35. Cortés-Sánchez Ade, J.; Hernández-Sánchez, H.; Jaramillo-Flores, M.E. Biological activity of glycolipids produced by microorganisms: New trends and possible therapeutic alternatives. Microbiol. Res. 2013, 168, 22-32. [CrossRef] [PubMed] 
36. De la Fuente-Núñez, C.; Reffuveille, F.; Fernández, L.; Hancock, R.E.W. Bacterial biofilm development as a multicellular adaptation: Antibiotic resistance and new therapeutic strategies. Curr. Opin. Microbiol. 2013, 16, 580-589. [CrossRef] [PubMed]

37. Rabin, N.; Zheng, Y.; Opoku-Temeng, C.; Du, Y.; Bonsu, E.; Sintim, H.O. Biofilm formation mechanisms and targets for developing antibiofilm agents. Future Med. Chem. 2015, 7, 493-512. [CrossRef] [PubMed]

38. Sambanthamoorthy, K.; Feng, X.; Patel, R.; Patel, S.; Paranavitana, C. Antimicrobial and antibiofilm potential of biosurfactants isolated from lactobacilli against multi-drug-resistant pathogens. BMC Microbiol. 2014, 14, 197. [CrossRef] [PubMed]

39. Folch, J.; Lees, M.; Stanley, G.H.S. A simple method for the isolation and purification of total lipides from animal tissues. J. Biol. Chem. 1957, 226, 497-509. [PubMed]

40. Leitão, E.A.; Bittencourt, V.C.B.; Haido, R.M.T.; Valente, A.P.; Peter-Katalinic, J.; Letzel, M.; de Souza, L.M.; Barreto-Bergter, E. B-galactofuranose-containing O-linked oligosaccharides present in the cell wall peptidogalactomannan of aspergillus fumigatus contain immunodominant epitopes. Glycobiology 2003, 13, 681-692. [CrossRef] [PubMed]

41. Sawardeker, J.S.; Sloneker, J.H.; Jeanes, A. Quantitative determination of monosaccharides as their alditol acetates by gas liquid chromatography. Anal. Chem. 1965, 37, 1602-1604. [CrossRef]

42. Calixto, R.O.R.; Rollin-Pinheiro, R.; da Silva, M.I.D.; Liporagi-Lopes, L.C.; Vieira, J.M.; Sassaki, G.L.; Barreto-Bergter, E. Structural analysis of glucosylceramides (GlcCer) from species of the pseudallescheria/scedosporium complex. Fungal Biol. 2016, 120, 166-172. [CrossRef] [PubMed]

43. Marinho, P.R.; Muricy, G.R.S.; Silva, M.F.L.; de Marval, M.G.; Laport, M.S. Antibiotic-resistant bacteria inhibited by extracts and fractions from brazilian marine sponges. Rev. Bras. Farmacogn. 2010, 20, 267-275. [CrossRef]

44. Hili, P.; Evans, C.S.; Veness, R.G. Antimicrobial action of essential oils: The effect of dimethylsulphoxide on the activity of cinnamon oil. Lett. Appl. Microbiol. 1997, 24, 269-275. [CrossRef] [PubMed]

45. Mosmann, T. Rapid colorimetric assay for cellular growth and survival: Application to proliferation and cytotoxicity assays. J. Immunol. Methods 1983, 65, 55-63. [CrossRef]

Sample Availability: Samples of the compounds monohexosylceramides (CMH) are available from the authors.

(c) 2018 by the authors. Licensee MDPI, Basel, Switzerland. This article is an open access article distributed under the terms and conditions of the Creative Commons Attribution (CC BY) license (http:/ / creativecommons.org/licenses/by/4.0/). 